\title{
STEPHAN HAERING
}

Ludwig Maximilian University of Munich, Germany

(D) https://orcid.org/0000-0003-2679-5107

\section{Synods and Synodal Processes in Germany since the Second Vatican Council}

\begin{abstract}
The present article provides an overview of the particular synods that have been conducted since the Second Vatican Council in Germany. It also takes into account those counseling processes that cannot be qualified as canonical synods.
\end{abstract}

Keywords: Catholic Church, synods in Germany from 1965 to 2016

\section{Introduction}

Pope Francis has repeatedly spoken about it and declared it as his desire that the synodal organs and generally the synodal process ${ }^{1}$ in the Church should gain a broader scope and greater importance. The pope has not thereby spoken of a new structural element in the Church as if it were/had been a new development or even a new idea for him. On the

${ }^{1}$ Cf. N. WiTsch: entry "Synodalität." In: Lexikon für Kirchen- und Staatskirchenrecht. Vol. 3. Paderborn 2004, pp. 642-644; W. Aymans: entry "Synodales Prinzip." In: Lexikon des Kirchenrechts. Freiburg-Basel-Wien 2004, col. 929-930; M. Augusto Santos: entry "Sinodalidad." In: Diccionario general de derecho canónico. Vol. 7, Cizur Menor 2012, pp. 341-345; S. Haering: “Autorität und Synodalität im Gesetzbuch der lateinischen Kirche." In: Autorität und Synodalität. Eine interdisziplinäre und interkonfessionelle Umschau nach ökumenischen Chancen und ekklesiologischen Desideraten. Eds. C. Böttigheimer, J. Hofmann. Frankfurt am Main 2008, pp. 297-320; M. Graulich: "Synodalität als Kennzeichen einer missionarischen Kirche" In: Ius semper reformandum. Reformvorschläge aus der Kirchenrechtswissenschaft. Eds. T. Meckel, M. Pulte. Paderborn 2018 (= Kirchen- und Staatskirchenrecht 28), pp. 115-127. 
contrary, the synods belong to the oldest institutions of the Church. Historically, they appeared in different forms and have also been of varied importance in the life of the Church.

The most important event in the 20th-century Church was surely a synod, namely the Second Vatican Council (1962-1965). ${ }^{2}$ This council was the beginning of an important momentum for a renewed appreciation of the synodal process in the Church and the basis for a boom in the synodal ideas.

In line with this, the pope made the following remarks in his speech on the occasion of the 50th anniversary of the synod of bishops on 17 November 2015: "a synodal Church is a listening Church, conscious of the fact that to listen to something is more than just to hear it. It is an interactive listening to one another, where everybody has something to learn. The faithful people of God, the college of bishops, the bishop of Rome: each one listens to the other one and together they listen to the Holy Spirit, the Spirit of truth (John 14, 27), so that they will be able to understand what He is saying to His Church (Acts of the Apostles 2, 7)."

It is the intention of this article to investigate the particular kind of development that the synodal element in Germany has gone through after almost half a century since the end of the Second Vatican Council. Considering the said thematic scope, it cannot however be anything more than just a brief overview. Such an assurance might also be valuable and important in facilitating the synodal elements as desired by Pope Francis; it can contribute towards a sustained implementation of this intention of the pope. ${ }^{4}$

When discussing Germany, it has to be pointed out right from the onset that it is only since 1990 that Germany as a unified country can be taken into account. A quarter of a century prior to this, that is, from the end of the council in 1965 until the re-unification of Germany, we

2 See: G. Alberigo, K. Wittstadt (vols. 1-3), G. Wassilowsky (vols. 4-5) (eds.): Geschichte des Zweiten Vatikanischen Konzils (1959-1965). 5 vols., Mainz resp. Ostfildern / Leuven 1997-2009; A. Marchetto: entry “Concilio Vaticano II." In: Diccionario general de derecho canónico. Vol. 2. Cizur Menor 2012, pp. 400-406 (bibl.).

3 Acta Apostolicae Sedis 107 (2015), pp. 1138-1144, here: p. 1140: "Una Chiesa sinodale è una Chiesa dell'ascolto, nella consapevolezza che ascoltare «è più che sentire». È un ascolto reciproco in cui ciascuno ha qualcosa da imparare. Popolo fedele, Collegio episcopale, Vescovo di Roma: l'uno in ascolto degli altri; e tutti in ascolto dello Spirito Santo, lo «Spirito della verità» $(\mathrm{Gv} 14,17)$, per conoscere ciò che Egli «dice alle Chiese» (Ap 2, 7)."

${ }^{4}$ Cf. also S. Demel: "Synoden — synodale Prozesse - Synodalität. Die nachkonziliare Entwicklung im Bereich der Deutschen Bischofskonferenz." In: Unverbindliche Beratung oder kollegiale Steuerung? Kirchenrechtliche Überlegungen zu synodalen Vorgängen. Eds. W. Rees, J. Schmiedl. Freiburg—Basel—Wien 2014, pp. 68-86. 
had had two very different, separate states: the Federal Republic of Germany (BRD, West Germany) and the Democratic Republic of Germany (DDR, East Germany). In both of them, the states belonging to different socio-political systems, the Catholic Church had to obviously grapple with divergent pre-existing requirements and conditions for her existence and mission.

Another preliminary remark concerns the concept of "synod," which forms the basis of this article. Here we are not dealing with the notion of synod in the strict sense, as it is found in the church tradition and canon law, wherein it is understood as episcopal collegial organs with, if need be, the participation of individuals who are not bishops, that is both, clerics and lay faithful. ${ }^{5}$ We are rather talking about all the legal institutions of the Church which serve the collective consultation of the faithful and which do not have permanent, but rather temporary character. This broad distinction is to the extent justified, as the law book of the Latin Church, the Codex Iuris Canonici (CIC) used the expression "synod" for the institutionalised assembly in a diocese under the leadership of the bishop, namely the diocesan synod (c. 460-468). To distinguish between synods in the strict sense, the canon law of the Catholic Eastern Churches, which (not only) in this regard is more precise as the CIC in legal terms, correctly calls the correspondent institutions of the dioceses of the Eastern Churches "Eparchial Convent" (cc. 235-242 CCEO).

Not taken into consideration is the activity of the conferences of bishops, that is, the German Bishops' Conference, which was established as a juridical body in 1966, and the Berlin Bishops' Conference, which existed from 1976 till 1990 before the reunification of Germany. ${ }^{6}$ In a wider sense, this form of episcopal collegial activity can be grouped under the synodal element in the Church, but the conferences of bishops are nevertheless permanent establishments and fit less to the fixed definition like the permanent advisory organs at the different levels in the Church.

${ }^{5}$ Cf. W. Aymans: Das synodale Element in der Kirchenverfassung. München 1970 (= Münchener Theologische Studien. Kanonistische Abteilung 30).

${ }^{6}$ Cf. H. Hallermann: entry "Deutsche Bischofskonferenz." In: Lexikon für Kirchenund Staatskirchenrecht. Vol. 1. Paderborn 2000, pp. 408-410; H. Schmitz: entry "Deutsche Bischofskonferenz." In: Lexikon des Kirchenrechts (see footnote 1), col. 117122. 


\section{Joint Synod of the Dioceses in the Federal Republic of Germany (Würzburger Synode)}

In the years following the Second Vatican Council there was an increase in the desire of many people in authority in the Catholic Church in Germany, to take up and concretise the proposals and ideas outlined by the council, not only at the diocesan, but also at the national level. This objective was implemented through a variety of events. Already in 1966 , a pastoral council was opened in the neighbouring country of the Netherlands in order to continue the ideas and decisions of the Second Vatican Council and to implement them in the country. ${ }^{7}$ In West Germany, it became evident through the discussions taking place at the Catholic Congress in Essen in 1968 and through the awakening throughout the society, which was linked to the event of the year 1968, that people had to talk with one another in the Church and agree on the way forward in the future. ${ }^{8}$

The German Bishops' Conference decided in 1969 to hold a General Synod of all the Dioceses. The preparation was rapidly and vigorously undertaken by a special commission which was set up in 1969 by the German Bishops' Conference for this purpose. An attempt was made through questionnaires distributed among the German Catholics to get the entire Catholic population involved in the said preparations. A bylaw was drafted which formed the basis upon which an intensive canonical discussion was developed. ${ }^{9}$

In January 1971, the inaugural plenary assembly of the synod was held in Würzburg. Subsequently, a total of eight plenary assemblies were held before its conclusion in 1975. In addition to this, several commissions of the synod held their respective meetings to discuss special areas

7 Cf. J. B. M. Wissink: "Die Organisation des Niederländischen Pastoralkonzils.” In: Unverbindliche Beratung oder kollegiale Steuerung? (see footnote 4), pp. 121-126.

${ }^{8}$ For more information on the preparation and celebration of this synod, cf. K. Lehmann: "Allgemeine Einleitung." In: Gemeinsame Synode der Bistümer in der Bundesrepublik Deutschland. Beschlüsse der Vollversammlung. Offizielle Gesamtausgabe I. 7th ed., Freiburg-Basel-Wien 1989, pp. 21-67.

${ }^{9}$ Cf. H. HallermanN: "Die Würzburger Synode - ein Maßstab für synodale Prozesse?" In: Recht - Bürge der Freiheit. Festschrift für Johannes Mühlsteiger SJ zum 80. Geburtstag. Eds. K. Breitsching, W. ReEs. Berlin 2006 (= Kanonistische Studien und Texte 51), pp. 621-644; IDEM: "Das Statut der Gemeinsamen Synode der Bistümer in der Bundesrepublik Deutschland." In: Unverbindliche Beratung oder kollegiale Steuerung? (see footnote 4), pp. 87-104; P. LeIBInger: "Gemeinsame Synode der Bistümer in der Bundesrepublik Deutschland 1971-1975." In: Synodale Prozesse in der katholischen Kirche. Eds. W. ReEs, L. Müller. Innsbruck 2016, pp. 97-124. 
and topical issues, which were of great importance to the synod and which contributed immensely in the preparation of its final resolutions. The synod produced a total of 18 resolutions and documents touching on the various areas on the life and mission of the Church.

The synod was composed of around 300 members. Besides the bishops, other clerics, the religious and the laity were represented with voting rights. The proportional participation of the lay faithful was around 140 members. Apart from the automatic members of the synod which in most part were bishops, the members were chosen by the different councils and associations through election. ${ }^{10} \mathrm{~A}$ distinctive feature was the equal voting right of all the participants, a provision that was unknown in canon law in this form. Different elements of the synodal rules provoked very strong canonical criticisms. ${ }^{11}$

The joint synod appeared to have been influenced in its structure and method strongly by the democratic parliamentary practices rather than by the classical synodal tradition. The Constitution of the joint synod as approved by the Holy See provided in its Article 13 that no decision can be taken on any issue if the German Bishops' Conference declares that it cannot support such a decision on grounds of faith and moral or if it refuses to guarantee the canonical implementation of decisions with legal contents. It merely refers to veto clauses, which does not basically negate the magisterial and legislative competence of the joint synod.

In the first years following the conclusion of the Würzburg Synod, its resolutions were very quickly published and also assimilated in the theological discussions and to some extent in the ecclesiastical practice. Gradually however, nothing was heard again about the joint synod and its documents. A variety of reasons contributed probably to this development. The process of adaptation of the documents of the Second Vatican Council itself was far from being completed and the teachings of the council simply drew more attention to itself than the resolutions of the particular synod. Pope John Paul II (1978-2005) presented important personal magisterial documents which in turn continued and developed the doctrine of the council. The revised Code of Canon Law - the Codex

${ }^{10}$ See the list of the members in: Gemeinsame Synode der Bistümer in der Bundesrepublik Deutschland. Ergänzungsband: Arbeitspapiere der Sachkommissionen. Offizielle Gesamtausgabe II. 4th ed. Freiburg-Basel-Wien 1985, pp. 266-299.

11 Cf. W. Aymans: "Synode 1972. Strukturprobleme eines Regionalkonzils." Archiv für katholisches Kirchenrecht 138 (1969), pp. 363-388; IDEM: “Ab Apostolica Sede recognitum. Erwägungen zu der päpstlichen Bestätigung des Statutes für die Gemeinsame Synode der Bistümer in der Bundesrepublik Deutschland." Archiv für katholisches Kirchenrecht 139 (1970), pp. 405-427; IDEM: "Synodalstatut — Kritik einer Verteidigung." Archiv für katholisches Kirchenrecht 140 (1971), pp. 136-146. 
Iuris Canonici, which was promulgated and came into effect in 1983, also attracted attention in the same way and forced the resolutions of the joint synod, which were by no means only temporary, rather to the contrary. ${ }^{12}$

At the commemoration of the 50th anniversary of the beginning of the Second Vatican Council, a new edition of all the documents of the joint synod was published, not least at the suggestion of Cardinal Karl Lehmann (1936-2018). ${ }^{13}$ Lehmann, who himself as a young theology professor was a committed member of the synod and saw to the publication of the synodal acts, wanted to draw a renewed attention to that event and resolutions passed at the time. Actually, the joint synod received a certain new attention in the context of the jubilee celebration of the council.

\section{Pastoral Synod in East Germany (Democratic Republic of Germany)}

On the opposite side the Iron Curtain, in the Democratic Republic of Germany (DDR), a joint synod for all the areas of jurisdiction was held similar to the one held in the Federal Republic of German (BRD). The Berlin Conference of Ordinaries which was a merger of the heads of the dioceses and other areas of ecclesiastical jurisdictions within the territory of the DDR resolved in 1971 to hold a pastoral synod. This synod took place in Dresden from 1973 to 1975 and met in seven sessions. The members included the Bishops of East Germany and 142 other synod participants, of which up to $50 \%$ were lay people in accordance with the bylaw of the synod. The pastoral synod passed a resolution on nine decrees as recommendations for the Berlin Conference of Ordinaries.

The coming into being of this synod was occasioned and facilitated by various factors. Of particular importance was the preceding diocesan synod of the diocese of Meissen, which was supposed to help in the implementation of the decisions of the Second Vatican Council. Nevertheless, the West German model of a national synod comprising all the dioceses certainly played an important role, too.

${ }^{12}$ Cf. R. Althaus: Die Rezeption des Codex Iuris Canonici von 1983 in der Bundesrepublik Deutschland unter besonderer Berücksichtigung der Voten der Gemeinsamen Synode der Bistümer in der Bundesrepublik Deutschland. Paderborn 2000 (= Paderborner Theologische Studien 28).

${ }_{13}$ Gemeinsame Synode der Bistümer in der Bundesrepublik Deutschland. Beschlüsse der Vollversammlung. Offizielle Gesamtausgabe. Mit einem Vorwort zur Neuausgabe von Karl Kardinal Lehmann. Freiburg- Basel-Wien 2012. 
The bylaw of the synod safeguarded the decisive leverage of the bishops in the decision-making process. ${ }^{14}$ The synodal resolutions were ultimately recommendations for the attention of the episcopate. Under the provisions of a hostile regime to the Church as was the case in East Germany, it appeared particularly wise to preclude undesirable political interferences through appropriate jurisdictional provisions.

\section{Diocesan synods}

The diocesan synod has a very long canonical tradition and belongs to the classical consultative organs of the bishop. In some German dioceses regular diocesan synods were held within the relevant spaces of time as laid down by the Code of Canon Law. ${ }^{15}$ Prior to the joint synod project for the Federal Republic of Germany, a diocesan synod was already held in 1968-1969 in the diocese of Hildesheim. Understandably, after the joint synod, there was for some time no need to hold a separate synod in the German dioceses.

It was not until about a decade later and after the Code of Canon of 1983 had already come into effect that diocesan synods were convened again. ${ }^{16}$ In the diocese of Rottenburg-Stuttgart a synod was held in

${ }^{14}$ Cf. Dominicus M. Meier: Das Statut der Pastoralsynode der Jurisdiktionsbezirke in der DDR: Unverbindliche Beratung oder kollegiale Steuerung? (see footnote 4), pp. 105-120.

15 Cf. H. PaArhammer: "Die Diözesansynode in ihrer gegenwärtigen Rechtsgestalt. Anmerkungen zum geltenden Recht und zu partikulären Neuentwicklungen des kirchlichen Synodalwesens auf Diözesanebene." In: Neue Positionen des Kirchenrechts. Eds. K. Lüdicke, H. PaArhammer, D.A. Binder. Graz 1994, pp. 81-117; J. Hirnsperger: “Die Diözesansynode. Bemerkungen zu den einschlägigen Normen des CIC unter besonderer Berücksichtigung der Instruktion vom 19. März 1997.” In: Dem Staate, was des Staates - der Kirche, was der Kirche ist. Festschrift für Joseph Listl zum 70. Geburtstag. Eds. K. LüDICKe, H. PaARhammer, D.A. Binder. Berlin 1999 (= Staatskirchenrechtliche Abhandlungen 33), pp. 855-873 (reprintet: Synodale Prozesse in der katholischen Kirche [see footnote 9], pp. 55-75); A. Viana: entry "Sínodo diocesano." In: Diccionario general de derecho canónico. Vol. 7, Cizur Menor 2012, pp. 350-354; C. OHLy: "Diözesansynode. Kirchenrechtliche Streiflichter zu einer traditionsreichen Kirchenversammlung." Trierer Theologische Zeitschrift 122 (2013), pp. 239-257; H. Schmitz: “Die Konsultationsorgane des Diözesanbischofs." In: Handbuch des katholischen Kirchenrechts, 3rd ed. Eds. S. Haering, W. Rees, H. Schmitz. Regensburg 2015, pp. 620-637, here: pp. 622-626; M. VISIOLI: "Una forma privilegiata di produzione normativa nella chiesa locale: il sinodo diocesano.” Ephemerides Iuris Canonici 57 (2017), pp. 73-103.

${ }^{16}$ Cf. T. SchülLER: Die Rezeption der Würzburger Synode auf diözesaner Ebene. Diözesansynoden in deutschen Diözesen von 1975 bis heute: Unverbindliche Beratung oder kollegiale Steuerung? (see footnote 4), pp. 283-295. 
1985-1986, in Hildesheim in 1989-1990, and in Augsburg in 1990. Thereafter there was another period of inactivity for around two decades during which there were no diocesan synods in Germany. Instead of holding synods, other forms of diocesan assembly and consultation were conceived and implemented; we shall elaborate on that in a moment. The diocese of Trier eventually ventured to hold a diocesan synod, which held its meetings in different sessions from 2013 to $2016 .{ }^{17}$ This synod passed a resolution on a final document titled: "Called out - moving towards the future with courage". In this document, new approaches in the pastoral ministry were posited and concrete proposals given for their implementation.

As for the territory of East Germany, what has to be mentioned here is the already cited diocesan synod of the diocese of Meissen, which Bishop Otto Spuelbeck (1904-1970) convoked and which lasted from 1969 to 1971. This synod also formed a point of departure for the national pastoral synod.

\section{Other synod-related Institutions at the diocesan level: Forums, pastoral consultations}

In a number of German dioceses, temporary consultative procedures were undertaken during the two decades before the end of the millennium, which were more or less analogical to a diocesan synod. The decision to create such new synodal institutions was motivated by the fact that the diocesan synod was considered to be too rigid and anachronistic. The new forms were supposed to allow for a greater flexibility and not least a greater participation of the laity. ${ }^{18}$

For the conduct of these diocesan quasi-synods, which came under various descriptions, specific regulations were issued in each of the respec-

${ }^{17}$ Cf. C. OHLY: "Die Diözesansynode im Bistum Trier (2012-2016). Anmerkungen aus kirchenrechtlicher Perspektive." In: Synodale Prozesse in der katholischen Kirche (see footnote 9), pp. 207-235.

18 Cf. R. P. Klein: Diözesansynode - Forum - Pastoralgespräch: Kirchliches Recht als Freiheitsordnung. Gedenkschrift für Hubert Müller. Würzburg 1997 (= Forschungen zur Kirchenrechtswissenschaft 27), pp. 117-141; S. HAering: “'Wege suchen im Gespräch'. Kirchenrechtliche Überlegungen zur synodalen Mitverantwortung der Gläubigen." Stimmen der Zeit 216 (1998), pp. 689-699; F. LAPPEN: Vom Recht zu reden und vom Recht gehört zu werden. Synoden und Foren als Mittel der Teilhabe der Gläubigen an den Leitungsfunktionen der Kirche in Deutschland. Essen 2007 (= Münsterischer Kommentar zum CIC. Beihefte 46). 
tive dioceses. A diocesan forum was held in the archdiocese of Freiburg in 1990, in 1994-1995 in the diocese of Regensburg, and in 1996-1997 in the diocese of Munster. The archdiocese of Munich and Freising organised a "pastoral forum" from 1991 to 1994.

Other forms somehow deviated strongly in their character from the canonical diocesan synod. Archbishop Joachim Meisner of the archdiocese of Cologne initiated in 1993 a pastoral dialogue in his diocese, which resulted in a final assembly in 1996. A similar process was conducted in 1997-1998 in the archdiocese of Bamberg. From 1993 to 1996 a "pastoral dialogue" was held in the diocese of Würzburg.

The observable tendency not only in Germany, to - so to speak a new temporary para-canonical institutions of consultations at the diocesan level was responsible for the issuance of a separate instruction by the Apostolic See in 1997 on the convocation and execution of the diocesan synod. ${ }^{19}$ On the one hand, this document aimed to be positively supportive of the bishops by giving them assistance for the diocesan synod, but on the other hand, it also repressed the diverse para-canonical forms of diocesan (organs of) consultation. The diocesan synod was supposed to be strengthened as the classical forum of consultation for all those in authority in the diocese.

Nevertheless, further diocesan consultative processes were still conducted even later in some German dioceses, which of course in their conception tried to contrast from a diocesan synod. We are talking here of the "Consultations on the future of the pastoral ministry," which was held in the diocese of Osnabrück from 1997 to 2000 and in the diocese of Magdeburg from 2000-2006, as well as the Forum for the future of the archdiocese of Munich and Freising from 2008 to 2010.

With regard to the content, these institutions were concerned primarily with concrete issues regarding the pastoral plan and cooperation in the diocese, in particular the cooperation between the clergy and the laity. In this connection, it must be remembered that there are also many qualified lay theologians in Germany who are actively involved in the pastoral ministry on full-time basis as pastoral assistants and parish consultors. For this reason, there was need for a deep rooted clarification of pastoral issues, which arise not least from the increasingly noticeable dearth of priests. The results of the consultations led to the structural plans of the respective dioceses on the future of the pastoral ministry.

During these synodal proceedings, but also during the diocesan synods, specific sensitive topics in the Church that were mainly discussed in

${ }^{19}$ Acta Apostolicae Sedis 89 (1997), pp. 706-727; cf. J. Hirnsperger: “Die Diözesansynode..." (see footnote 15 ). 
western countries, but which could not at all be decided at the diocesan level repeatedly came up for discussion. There were particular issues like the admission to the priesthood, celibacy, the ordination of women to the diaconate or the situation of divorced and remarried members of the Church. ${ }^{20}$

\section{6. "Consultative process" of the German Bishops' Conference (2011-2015)}

As the Catholic Church in Germany was enjoying a higher level of attention and sympathy in the society following the election of Cardinal Joseph Ratzinger in 2005 as the bishop of Rome and the Shepherd of the Universal Church, the World Youth Day in Cologne in the same year and the visit of Pope Benedict XVI (2005-2013) to his Bavarian native home in September 2006, ${ }^{21}$ there was a noticeable backlash against the papacy around the middle of the pontificate of Benedict XVI, as can be said today in the hindsight. The Church now came under enormous pressure from the German public, particularly in the media and lost her reputation. Two recent reasons were primarily decisive in this respect.

On the one hand, there was the attempt by Pope Benedict to revoke the excommunication of the four bishops belonging to the Society of St. Pius X founded by Archbishop Marcel Lefebvre, thereby encouraging the reconcilement with this schismatic group. ${ }^{22}$ This action of the pope which was taken in 2009 was in Germany practically reported and commented by the media only under the headline "the rehabilitation of the holocaust denier Williamson." This was because one of the bishops, a Briton Rich-

${ }^{20}$ Cf. G. MAY: “Der Ruf nach mehr Synodalität." In: Theologia Iuris Canonici. Festschrift für Ludger Müller zur Vollendung des 65. Lebensjahres. Eds. C. OHLY, W. ReEs, L. Gerosa. Berlin 2017 (= Kanonistische Studien und Texte 67), pp. 223-248.

${ }^{21}$ Cf.: Apostolische Reise Seiner Heiligkeit Papst Benedikt XVI. nach München, Altötting und Regensburg. Predigten, Ansprachen und Grußworte. Ed. by Sekretariat der Deutschen BischofsKonferenz. Bonn 2006 (= Verlautbarungen des Apostolischen Stuhls 174).

${ }^{22}$ Cf. W. Beinert (ed.): Vatikan und Pius-Brüder. Anatomie einer Krise. 2nd ed., Freiburg-Basel-Wien 2009; S. HaERING: "Rom und die Piusbruderschaft. Ein kirchenrechtlicher Blick auf die Vorgänge des ersten Halbjahres 2009." Münchener Theologische Zeitschrift 60 (2009), pp. 247-257; IDEM: “Der Apostolische Stuhl und die Priesterbruderschaft St. Pius X.” Trierer Theologische Zeitschrift 119 (2010), pp. 287-308; B. Dennemarck, H. Hallermann, T. Meckel: Von der Trennung zur Einheit. Das Bemühen um die Pius-Bruderschaft. Würzburg 2011 (= Würzburger Theologie 7). 
ard Williamson, who was by then excommunicated, had doubted in an interview the reality of the murder of about six million Jews by the Nazi regime. This influenced negatively the public perception of events so much that the pope's intention to work for the unity of the Church remained largely unnoticed. The Church or the pope respectively, were depicted either as politically naive or at most as affectionately anti-Semitic. Even the German Chancellor Angela Merkel joined the discussion and called on the pope for clarification.

The second reason for the significant deterioration of the reputation of the Church among the German public was the disclosure in 2010 to the public of cases of sex abuse of children and youth by the clerics or in ecclesiastical quarters. ${ }^{23}$ Even though it became quickly clear that such misconducts and crimes were also found in all other social contexts and that it was here by no means an exclusively peculiar problem of the Church, public attention was still directed mainly towards real or supposed church offenders. The clumsy approach of some bishops in handling the matter gave the disastrous impression as if it had been all about a problem occurring specifically in the Church.

In any case the Church was under external pressure, but also under intense criticism from some groups of the faithful. It became visible that there was a significant potential of skepticism and even resentment towards the Catholic Church in the German society, which could be easily activated through scandalous events and their concentrated medial presentation. The result was a huge loss of respect and trust for the Church. The number of those who left the Catholic Church through their official declaration before the state authorities increased significantly.

Against this pressing backdrop, in the face of a serious crisis in the Church, and given the palpable general dissatisfaction among the faithful, the German Bishops' Conference initiated in the Fall of 2010 a special "process of consultation," that is, a totally different and new synodal procedure. It was titled "Believing in the present day." 24 At various events in the dioceses and at the entire national level in Germany, the situation in the Church was to be discussed and the consciousness of her mission

${ }^{23}$ Cf. S. Haering: "Die Kirche und die Erfahrungen des Jahres 2010." Archiv für katholisches Kirchenrecht 180 (2011), pp. 133-149; H. Hallermann, T. Meckel, S. Pfannkuche, M. Pulte (eds.): Der Strafanspruch der Kirche in Fällen von sexuellem Missbrauch. Würzburg 2012 (= Würzburger Theologie 9); R. Rieger (ed.): Auf dem Weg zu Heilung und Erneuerung. Das Symposium zum sexuellen Missbrauch Minderjähriger, Päpstliche Universität Gregoriana, 6.-9. Februar 2012. München 2012.

${ }^{24}$ M. Kirschner, J. Schmiedl (eds.): Der Dialog geht weiter. Ergebnisse und Perspektiven des Gesprächsprozesses. Freiburg-Basel-Wien 2016 (= Katholische Kirche im Dialog 4). 
reawaken. The process was to last over a period of five years, beginning in 2011 through 2015 before coming to a conclusion. Each of the years was respectively assigned a particular topic, namely:

- 2011: Believing in the present day - Where do we stand?

- 2012: Diakonia: Our responsibility in the free society

- 2013: Liturgia: The worship of God in the present time

- 2014: Martyria: Bearing witness to the faith in the world of today

- 2015: Believing in the present day - Where there is God, there is the future.

This process of consultation did not take place in the form of definite legal organs with a well-defined set of members, but was rather widely open for those persons, who were interested in participating in it. Forums were organized in each year, where the respective yearly topics were discussed. Each of these forums, which took place in different respective venues, brought around 300 persons together. The participation was not completely stable. There were participants who were present at all the forums, thereby giving the process a certain sense of continuity, while others, taking into consideration the respective topics and their specific competence to the topics, only featured in one or two congresses. The Conference of Bishops itself issued separate invitations only to 15 participants, while most of the participants were sent by the dioceses according to their respective sizes.

The central committee of Catholics in Germany, the German Conference of Religious Superiors, the German Caritas Organization, the Congress of Catholic-theology Faculties, the Spiritual Communities and other associations in the Church were also allowed to send their delegates.

The consultation process was not designed to pass resolutions, but to collectively promote mutual communication and renewal within the Church. And this is precisely the objective and the purpose of synods. The description of the consultation process as a spiritual process stands also in agreement with that of the synod, which always has a spiritual and liturgical character.

Taken as a whole, concrete results and effects of the consultation process are elusive. Doubtlessly the initiative helped people to increasingly engage each other in dialogue within the Church, in the knowledge that doing so is the best way to bring about dialogue between God and the faithful. At the end the nationwide consultation forum that took place from 11 to 12 September 2015 in Würzburg, the Conference of Bishops presented a concluding report, which could, however, only describe the event in general terms. ${ }^{25}$

${ }^{25}$ Überdiözesaner Gesprächsprozess „Im Heute glauben“. Abschlussbericht. Ed. by Sekretariat der Deutschen Bischofskonferenz. Bonn [2015]. 


\section{Concluding remarks}

The presented overview of the synods and synodal processes which have been conducted in the Germany since the Second Vatican Council reveals first of all that the synodal element in Germany in these decades has received quite a remarkable attention. Synods and synod-related assemblies in their various forms were conducted, which were supposed to be of benefit to the life and witness of the Church. ${ }^{26}$

With reference to the multiplicity of the various forms, the classical institutions of canon law play noticeably a rather minor role. Provincial councils according to c. 440 CIC never took place at all. Only a few diocesan synods within the relevant period under consideration were organized and conducted in accordance with the provisions of the Code of Canon Law. But nevertheless, this brought about many para-canonical synodal processes at the diocesan level. Even the joint synod of the dioceses in the Federal Republic of Germany (BRD) and the pastoral synod of the districts under the jurisdiction of the Democratic Republic of Germany (DDR) were no classical plenary councils in accordance with canonical regulations. The consultative process of the German Bishops' Conference which was organized between 2001 and 2015 is only faintly a reminiscent of a synod.

Strictly seen from the juridical point of view, neither the real synods nor the alternative consultative organs were actually of great importance. The lawmaker and the policy maker were the bishops or the Bishops' Conference respectively. Indirectly however, the synodal organs may have had some influence on episcopal legislation. But on the whole, they were concerned above all about the promotion of internal synergy in the church in the form which the faithful have known it from the democratic organs of the civil government.

The limited significance of the synodal organs in Germany may also be associated with the fact that existing councils and committees that were involved in shaping the life of the church were constantly established at all levels of the church. There exists the central committee of the German Catholics ${ }^{27}$, which operates nationwide and the respective Committees of

${ }^{26}$ Cf. L. MülLER: "Konzilien, Synoden, Räte. Thesen zu ihrem Ort in der Kirche und zu ihrer Aufgabe." In: Synodale Prozesse in der katholischen Kirche (see footnote 9), pp. $169-180$.

${ }^{27}$ Cf. T. Grossmann: entry "Zentralkomitee der deutschen Katholiken: Lexikon des Kirchenrechts" (see footnote 1), col. 1019-1021; S. VeSPER: entry "Zentralkomitee der deutschen Katholiken." In: Handbuch Pfarrgemeinderat. Ed. by LANDESKOMITEE DeR KATHOLIKEN IN BAYERN. Freiburg-Basel-Wien 2012, pp. 246-248; further information and sources: www.zdk.de. 
Catholics in the individual states like Bavaria, North Rhine Westphalia and Lower Saxony. ${ }^{28}$ In every diocese there are Catholic Councils ${ }^{29}$ as well as Deanery and Parish councils ${ }^{30}$ at other ecclesiastical levels which are regularly active. In these organs interested lay people and the church associations have constantly the possibility to articulate themselves and contribute responsibly in shaping the life of the church. In the light of this, it appears explicable that the overall desire to hold synods in Germany remained rather limited.

${ }^{28}$ Cf. K. EDER: entry "Landeskomitee der Katholiken in Bayern." In: Handbuch Pfarrgemeinderat (see footnote 27), pp. 180-182; K. STIENECKE: entry "Landesarbeitsgemeinschaft der Diözesanräte in Nordrhein-Westfalen," In: ibid., pp. 176-177; H. NIEPÖTteR: entry "Landeskatholikenausschuss in Niedersachsen." In: ibid., pp. 177-179.

29 Cf. H. KüNZEL: Apostolatsrat und Diözesanpastoralrat. Geschichte, kodikarische Vorgaben und Ausgestaltung in Deutschland. Essen 2002 (= Münsterischer Kommentar zum CIC.B 36); IDEm: "Diözesan- und Pastoralräte in Deutschland - eine Bestandsaufnahme." Forum Katholische Theologie 20 (2004), pp. 282-292.

30 Cf. F. KALDE: "Pfarrpastoralrat, Pfarrgemeinderat und Pfarrvermögensverwaltungsrat." In: Handbuch des katholischen Kirchenrechts... (see footnote 15), pp. 737-745, here: pp. 737-742.

\section{Bibliography}

Alberigo G., Wittstadt K. (vol. 1-3), Wassilowsky G. (vol. 4-5) (eds.): Geschichte des Zweiten Vatikanischen Konzils (1959-1965). 5 vol. Mainz resp. Ostfildern/Leuven 1997-2009.

Althaus R.: Die Rezeption des Codex Iuris Canonici von 1983 in der Bundesrepublik Deutschland unter besonderer Berücksichtigung der Voten der Gemeinsamen Synode der Bistümer in der Bundesrepublik Deutschland. Paderborn 2000 (= Paderborner Theologische Studien 28).

Apostolische Reise Seiner Heiligkeit Papst Benedikt XVI. nach München, Altötting und Regensburg. Predigten, Ansprachen und Grußworte. Ed. by SeKreTARiat der Deutschen BischofsKonferenz. Bonn 2006 (= Verlautbarungen des Apostolischen Stuhls 174).

Aymans W.: "Synode 1972. Strukturprobleme eines Regionalkonzils." Archiv für katholisches Kirchenrecht 138 (1969), pp. 363-388.

Aymans W.: Das synodale Element in der Kirchenverfassung. München 1970 (= Münchener Theologische Studien. Kanonistische Abteilung 30).

Aymans W.: “Ab Apostolica Sede recognitum. Erwägungen zu der päpstlichen Bestätigung des Statutes für die Gemeinsame Synode der Bistümer in der Bundesrepublik Deutschland.“ Archiv für katholisches Kirchenrecht 139 (1970), pp. 405-427. 
Aymans W.: “Synodalstatut - Kritik einer Verteidigung." Archiv für katholisches Kirchenrecht 140 (1971), pp. 136-146.

Aymans W.: entry "Synodales Prinzip." Lexikon des Kirchenrechts. FreiburgBasel-Wien 2004, col. 929-930.

Beinert W. (ed.): Vatikan und Pius-Brüder. Anatomie einer Krise. 2nd ed. Freiburg-Basel-Wien 2009.

CONGREgatio PRO EPISCOPIS - CONGREgatio PRO GENTIUM EVANGElizatione: "Instructio De Synodis dioecesanis agendis." Acta Apostolicae Sedis 89 (1997), pp. 706-727.

Demel S.: "Synoden - synodale Prozesse — Synodalität. Die nachkonziliare Entwicklung im Bereich der Deutschen Bischofskonferenz." Unverbindliche Beratung oder kollegiale Steuerung? Kirchenrechtliche Überlegungen zu synodalen Vorgängen. Eds. W. ReEs, J. Schmiedl. Freiburg-Basel-Wien 2014, pp. $68-86$.

Dennemarck B., Hallermann H., Meckel T. (eds.): Von der Trennung zur Einheit. Das Bemühen um die Pius-Bruderschaft. Würzburg 2011 (= Würzburger Theologie 7).

EDER K.: entry: “Landeskomitee der Katholiken in Bayern.” In: Handbuch Pfarrgemeinderat. Ed. by LANDESKOMITEe Der Katholiken In Bayern. FreiburgBasel-Wien 2012, pp. 180-182.

FrancIscus: "Allocutio Occasione L anniversariae memoriae ab inita Synodo Episcoporum." Acta Apostolicae Sedis 107 (2015), pp. 1138-1144.

Gemeinsame Synode der Bistümer in der Bundesrepublik Deutschland. Ergänzungsband: Arbeitspapiere der Sachkommissionen. Offizielle Gesamtausgabe II. 4th ed. Freiburg-Basel-Wien 1985

Gemeinsame Synode der Bistümer in der Bundesrepublik Deutschland. Beschlüsse der Vollversammlung. Offizielle Gesamtausgabe. Mit einem Vorwort zur Neuausgabe von Karl Kardinal Lehmann. Freiburg-Basel—Wien 2012.

Graulich M.: “Synodalität als Kennzeichen einer missionarischen Kirche.” Ius semper reformandum. Reformvorschläge aus der Kirchenrechtswissenschaft. Eds. T. Meckel, M. Pulte. Paderborn 2018 (= Kirchen- und Staatskirchenrecht 28), pp. 115-127.

Grossmann T.: entry: „Zentralkomitee der deutschen Katholiken.” Lexikon des Kirchenrechts. Freiburg-Basel-Wien 2004, col. 1019-1021.

HAERING S.: “'Wege suchen im Gespräch'. Kirchenrechtliche Überlegungen zur synodalen Mitverantwortung der Gläubigen.” Stimmen der Zeit 216 (1998), pp. 689-699.

Haering S.: "Autorität und Synodalität im Gesetzbuch der lateinischen Kirche." In: Autorität und Synodalität. Eine interdisziplinäre und interkonfessionelle Umschau nach ökumenischen Chancen und ekklesiologischen Desideraten. Eds. C. Böttigheimer, J. Hofmann. Frankfurt am Main 2008, pp. 297-320.

Haering S.: "Rom und die Piusbruderschaft. Ein kirchenrechtlicher Blick auf die Vorgänge des ersten Halbjahres 2009." Münchener Theologische Zeitschrift 60 (2009), pp. 247-257.

Haering S.: "Der Apostolische Stuhl und die Priesterbruderschaft St. Pius X." Trierer Theologische Zeitschrift 119 (2010), pp. 287-308. 
Haering S.: “Die Kirche und die Erfahrungen des Jahres 2010." Archiv für katholisches Kirchenrecht 180 (2011), pp. 133-149.

Hallermann H.: entry "Deutsche Bischofskonferenz." Lexikon für Kirchen- und Staatskirchenrecht, vol. 1. Paderborn 2000, pp. 408-410.

Hallermann H.: "Die Würzburger Synode - ein Maßstab für synodale Prozesse?" In: Recht - Bürge der Freiheit. Festschrift für Johannes Mühlsteiger SJ zum 80. Geburtstag. Eds. K. Breitsching, W. Rees. Berlin 2006 (= Kanonistische Studien und Texte 51), pp. 621-644.

Hallermann H.: “Das Statut der Gemeinsamen Synode der Bistümer in der Bundesrepublik Deutschland: Unverbindliche Beratung oder kollegiale Steuerung?" In: Unverbindliche Beratung oder kollegiale Steuerung? Kirchenrechtliche Überlegungen zu synodalen Vorgängen. Eds. W. REES, J. SCHMiedL. Freiburg-Basel-Wien 2014, pp. 87-104.

Hallermann H., Meckel T., Pfannkuche S., Pulte M. (eds.): Der Strafanspruch der Kirche in Fällen von sexuellem Missbrauch. Würzburg 2012 (= Würzburger Theologie 9).

Hirnsperger J.: “Die Diözesansynode. Bemerkungen zu den einschlägigen Normen des CIC unter besonderer Berücksichtigung der Instruktion vom 19. März 1997." In: Dem Staate, was des Staates - der Kirche, was der Kirche ist. Festschrift für Joseph Listl zum 70. Geburtstag. Eds. J. IsENsEe, W. REES, W. RüFNER. Berlin 1999 (= Staatskirchenrechtliche Abhandlungen 33), pp. 855-873 (repr.: Synodale Prozesse in der katholischen Kirche. Eds. W. ReEs, L. Müller. Innsbruck 2016, pp. 55-75).

KALDE F.: "Pfarrpastoralrat, Pfarrgemeinderat und Pfarrvermögensverwaltungsrat." In: Handbuch des katholischen Kirchenrechts. 3rd ed. Eds. S. HaERING, W. Rees, H. Schmitz. Regensburg 2015, pp. 737-745.

Kirschner M., Schmiedl J. (eds.): Der Dialog geht weiter. Ergebnisse und Perspektiven des Gesprächsprozesses. Freiburg-Basel-Wien 2016 (= Katholische Kirche im Dialog 4).

Klein R. P.: “Diözesansynode - Forum - Pastoralgespräch.” In: Kirchliches Recht als Freiheitsordnung. Gedenkschrift für Hubert Müller. Würzburg 1997 (= Forschungen zur Kirchenrechtswissenschaft 27), pp. 117-141.

KüNZEL H.: Apostolatsrat und Diözesanpastoralrat. Geschichte, kodikarische Vorgaben und Ausgestaltung in Deutschland. Essen 2002 (= Münsterischer Kommentar zum CIC. Beihefte 36)

KüNZEL H.: "Diözesan- und Pastoralräte in Deutschland - eine Bestandsaufnahme.” Forum Katholische Theologie 20 (2004), pp. 282-292.

LAPPEN F.: Vom Recht zu reden und vom Recht gehört zu werden. Synoden und Foren als Mittel der Teilhabe der Gläubigen an den Leitungsfunktionen der Kirche in Deutschland. Essen 2007 (= Münsterischer Kommentar zum CIC. Beihefte 46).

LEHMANN K.: Allgemeine Einleitung: Gemeinsame Synode der Bistümer in der Bundesrepublik Deutschland. Beschlüsse der Vollversammlung. Offizielle Gesamtausgabe I. 7th ed. Freiburg-Basel-Wien 1989, pp. 21-67.

Leibinger P.: "Gemeinsame Synode der Bistümer in der Bundesrepublik Deutschland 1971-1975." In: Synodale Prozesse in der katholischen Kirche. Eds. W. ReEs, L. MüLler. Innsbruck 2016, pp. 97-124. 
Marchetto, A.: entry: Concilio Vaticano II: Diccionario general de derecho canónico, vol. 2. Cizur Menor 2012, pp. 400-406.

May G.: “Der Ruf nach mehr Synodalität." Theologia Iuris Canonici. Festschrift für Ludger Müller zur Vollendung des 65. Lebensjahres. Eds. C. OHLY, W. Rees, L. Gerosa. Berlin 2017 (= Kanonistische Studien und Texte 67), pp. $223-248$.

Meier D. M.: “Das Statut der Pastoralsynode der Jurisdiktionsbezirke in der DDR: Unverbindliche Beratung oder kollegiale Steuerung?” In: Unverbindliche Beratung oder kollegiale Steuerung? Kirchenrechtliche Überlegungen zu synodalen Vorgängen. Eds. W. ReEs, J. SchmiedL. Freiburg-Basel-Wien 2014, pp. 105-120.

Müller L.: "Konzilien, Synoden, Räte. Thesen zu ihrem Ort in der Kirche und zu ihrer Aufgabe: Synodale Prozesse in der katholischen Kirche.” In: Synodale Prozesse in der katholischen Kirche. Eds. W. ReEs, L. Müller. Innsbruck 2016, pp. 169-180.

Niepötter H.: entry: “Landeskatholikenausschuss in Niedersachsen.” In: Handbuch Pfarrgemeinderat. Ed. by LANDESKOMITEe DeR KATHOLIKEN IN BAYERN. Freiburg-Basel-Wien 2012, pp. 177-179.

OHLY C.: "Diözesansynode. Kirchenrechtliche Streiflichter zu einer traditionsreichen Kirchenversammlung. " Trierer Theologische Zeitschrift 122 (2013), pp. $239-257$.

Oнцy C.: „Die Diözesansynode im Bistum Trier (2012-2016). Anmerkungen aus kirchenrechtlicher Perspektive: Synodale Prozesse in der katholischen Kirche." In: Synodale Prozesse in der katholischen Kirche. Eds. W. ReEs, L. Müller. Innsbruck 2016, pp. 207-235.

PaArhammer H.: “Die Diözesansynode in ihrer gegenwärtigen Rechtsgestalt. Anmerkungen zum geltenden Recht und zu partikulären Neuentwicklungen des kirchlichen Synodalwesens auf Diözesanebene.“ In: Neue Positionen des Kirchenrechts. Eds. K. Lüdicke, H. Paarhammer, D. A. Binder. Graz 1994, pp. 81-117.

Rieger R. (ed.): Auf dem Weg zu Heilung und Erneuerung. Das Symposium zum sexuellen Missbrauch Minderjähriger. Päpstliche Universität Gregoriana, 6.-9. Februar 2012. München 2012.

Santos M. A.: entry: “Sinodalidad." Diccionario general de derecho canónico, vol. 7. Cizur Menor 2012, pp. 341-345.

Schmitz H.: entry: "Deutsche Bischofskonferenz." Lexikon des Kirchenrechts. Freiburg- Basel-Wien 2004, col. 117-122.

Schmitz H.: "Die Konsultationsorgane des Diözesanbischofs." In: Handbuch des katholischen Kirchenrechts, 3rd ed. Eds. S. Haering, W. Rees, H. Schmitz. Regensburg 2015, pp. 620-637.

SChülleR T.: “Die Rezeption der Würzburger Synode auf diözesaner Ebene. Diözesansynoden in deutschen Diözesen von 1975 bis heute: Unverbindliche Beratung oder kollegiale Steuerung?" In: Unverbindliche Beratung oder kollegiale Steuerung? Kirchenrechtliche Überlegungen zu synodalen Vorgängen. Eds. W. Rees, J. SchmiedL. Freiburg-Basel—Wien 2014, pp. 283-295. 
STIENECKe K.: entry: “Landesarbeitsgemeinschaft der Diözesanräte in Nordrhein-Westfalen." In: Handbuch Pfarrgemeinderat. Ed. by LANDESKOMITEE DER Katholiken in Bayern. Freiburg-Basel-Wien 2012, pp. 176-177.

Überdiözesaner Gesprächsprozess „Im Heute glauben”. Abschlussbericht. Ed. by Sekretariat der Deutschen Bischofskonferenz. Bonn [2015].

Vesper S.: entry: "Zentralkomitee der deutschen Katholiken: Handbuch Pfarrgemeinderat." Ed. by Landeskomitee der Katholiken in Bayern. FreiburgBasel-Wien 2012, pp. 246-248.

VianA A.: entry: "Sínodo diocesano." Diccionario general de derecho canónico, vol. 7. Cizur Menor 2012, pp. 350-354.

VISIOLI M.: "Una forma privilegiata di produzione normativa nella chiesa locale: il sinodo diocesano.“ Ephemerides Iuris Canonici 57 (2017), pp. 73-103.

Wissink J. B. M.: “Die Organisation des Niederländischen Pastoralkonzils: Unverbindliche Beratung oder kollegiale Steuerung?” In: Unverbindliche Beratung oder kollegiale Steuerung? Kirchenrechtliche Überlegungen zu synodalen Vorgängen. Eds. W. ReEs, J. SchmiedL. Freiburg-Basel-Wien 2014, pp. $121-126$.

Witsch N.: entry: "Synodalität." Lexikon für Kirchen- und Staatskirchenrecht, vol. 3. Paderborn 2004, pp. 642-644.

STEPHAN HAERING

Synodes et processus synodal en Allemagne depuis le Concile Vatican II

Résumé

Cet article donne un aperçu des synodes particuliers qui ont eu lieu en Allemagne depuis le Concile Vatican II. Sont également inclus les processus consultatifs qui ne peuvent pas être qualifiés de synodes canoniques.

Mots-clés: Église catholique, synodes en Allemagne de 1965 à 2016

StePhan HaEring

Sinodi e processo sinodale in Germania dal Concilio Vaticano II

Sommario

Questo articolo fornisce una panoramica dei sinodi particolari che hanno avuto luogo in Germania dal Concilio Vaticano II. Sono inclusi anche quei processi consultivi che non possono essere qualificati da sinodi canonici.

Parole chiave: Chiesa cattolica, sinodi in Germania dal 1965 al 2016 